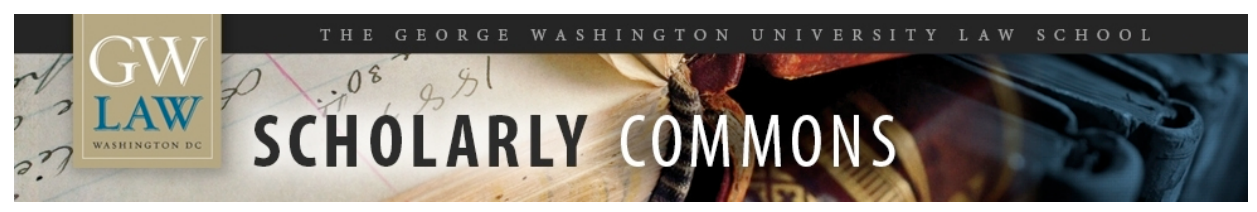

\title{
Public Procurement Systems: Unpacking Stakeholder Aspirations and Expectations
}

Steven L. Schooner

George Washington University Law School, sschooner@law.gwu.edu

Daniel I. Gordon

George Washington University Law School, dgordon@law.gwu.edu

Jessica L. Clark

George Washington University Law School, jclark05@law.gwu.edu

Follow this and additional works at: https://scholarship.law.gwu.edu/faculty_publications

Part of the Government Contracts Commons

\section{Recommended Citation}

Schooner, Steven L.; Gordon, Daniel I.; and Clark, Jessica L., "Public Procurement Systems: Unpacking Stakeholder Aspirations and Expectations" (2008). GW Law Faculty Publications \& Other Works. 111. https://scholarship.law.gwu.edu/faculty_publications/111

This Article is brought to you for free and open access by the Faculty Scholarship at Scholarly Commons. It has been accepted for inclusion in GW Law Faculty Publications \& Other Works by an authorized administrator of Scholarly Commons. For more information, please contact spagel@law.gwu.edu. 


\section{Public Procurement Systems: UNPACKING STAKEHOLDER ASPIRATIONS AND EXPECTATIONS}

\section{Steven L. Schooner, Daniel I. Gordon, and Jessica L. Clark}

\section{Table of Contents}

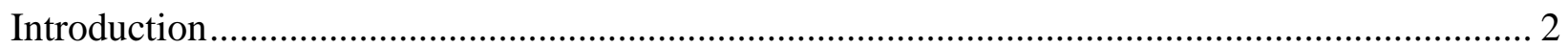

Part I: Competing Goals in Public Procurement...................................................................... 4

Goals and Constraints in Individual Purchasing................................................................ 4

Goals and Constraints in Private Company Purchasing ............................................................. 5

Goals and Constraints in Public Entity Purchasing ...................................................................... 6

Cluster 1: End User Satisfaction, Economy, Best Value, Efficiency, Risk Avoidance ............ 6

End User Satisfaction ................................................................................................. 6

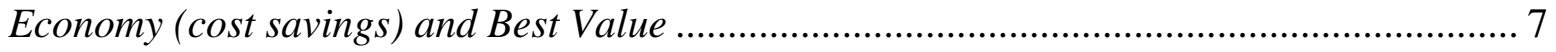

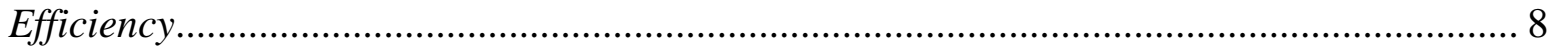

Risk Avoidance .......................................................................................................... 9

Cluster 2: Integrity, Uniformity, Transparency, Accountability, Competition....................... 10

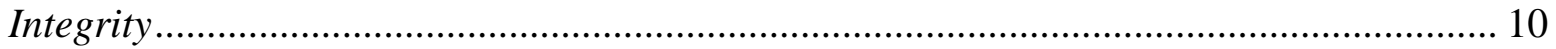

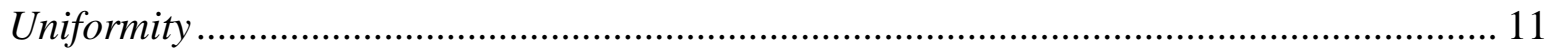

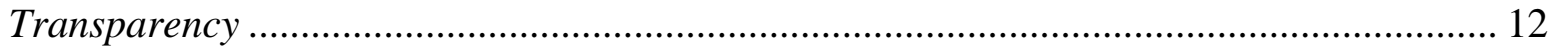

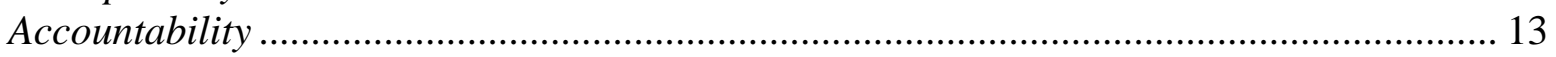

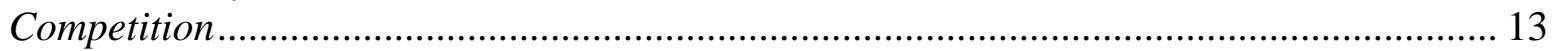

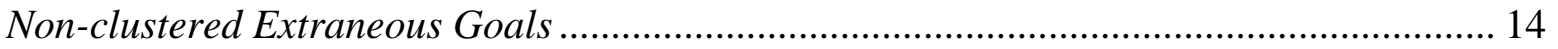

Investment through Targeted Procurement ……………................................................. 14

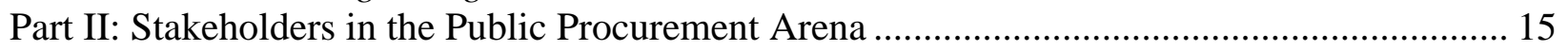

Inside Public Procurement Stakeholders ................................................................................. 17

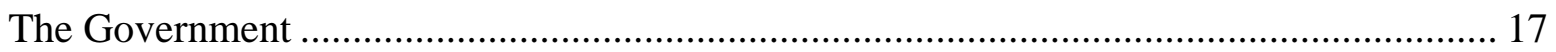

Outside Public Procurement Stakeholders........................................................................... 19

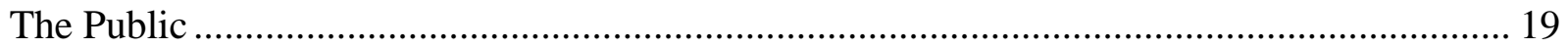

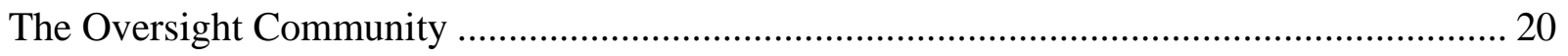

Government Oversight ..................................................................................................... 21

Non-Government Oversight......................................................................................... 21

Private Stakeholders.................................................................................................. 22

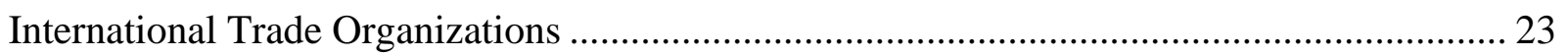

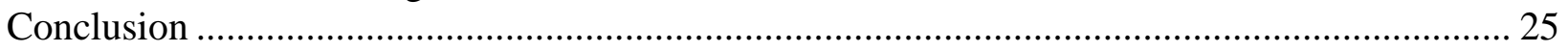




\section{Introduction}

Countries around the world, and sub-national governments within countries, are increasingly becoming focused on improving their public procurement regimes, both in terms of their legal form and their practical operation. ${ }^{1}$ Not surprisingly, procurement's central role in the economic and institutional growth of developing countries is being increasingly recognized by the World Bank as well as the Bank's member nations. ${ }^{2}$ Globally, and of interest to all countries, there is ongoing discussion among policy makers and third-party oversight groups about the links between improving procurement systems and fighting corruption, as highlighted by the Organisation for Economic Co-Operation and Development's work in that area. ${ }^{3}$

In terms of the changing legal framework, significant developments include the establishment of internationally shared norms for public procurement systems, such as the World Trade Organization's recently revised Agreement on Government Procurement. ${ }^{4}$ At the national level, over the past decade, a number of countries, such as China ${ }^{5}$ and Turkey, ${ }^{6}$ have adopted

\footnotetext{
${ }^{1}$ No doubt the size of the public procurement markets within these countries' economies is
} directly related to this focus. In 2002, the Organisation for Economic Co-Operation and Development (OECD) quantified the size of public procurement markets based on 1998 data: "For the OECD countries as a whole, the ratio of total procurement (consumption and investment expenditure) for all levels of government is estimated at 19.96\% or USD 4,733 billion, and for the non-OECD countries it is estimated at $14.48 \%$ or USD 816 billion." OECD, The Size of Government Procurement Markets (Nov. 2, 2002), available at http://www.oecd.org/dataoecd/34/14/1845927.pdf; see also European Union, EU Policy on Public Procurement, http://europa.eu/publicprocurement/index_en.htm (last visited Jan. 2, 2008) ("Public procurement, or $16.3 \%$ of the Community GDP, is an important sector of the European economy.”).

${ }^{2}$ See, e.g., Dr. Ngozi Okonjo-Iweala, Managing Director, World Bank Group, Opening Plenary of the Conference of State Parties to the United Nations Convention against Corruption, $A$ Global Partnership in the Fight against Corruption (Jan. 28, 2008), http://web.worldbank.org/WBSITE/EXTERNAL/NEWS/0,,contentMDK:21628209 pagePK:34 370 piPK:34424 theSitePK:4607,00.html.

${ }^{3}$ See generally OECD, INTegrity in Public Procurement: Good Practice From A to Z 17 (2007).

${ }^{4}$ World Trade Organization, Agreement on Government Procurement (Jan. 1, 1996), available at http://www.wto.org/english/tratop_e/gproc_e/gp_gpa_e.htm.

${ }^{5}$ See generally Cao Fuguo, Government Procurement and Innovation in China: A Review of Recent Developments, P.P.L.R. 2007, 6, 163-66; Cao Fuguo, Developments in China: The Regulations Implementing the Chinese Government Procurement Law, and Progress Towards GPA Accession, P.P.L.R. 2006, 6, 205-13. 
dramatically new public procurement regimes, and the accession of new member states to the European Union has led to equally dramatic changes in the procurement law systems of those new members. ${ }^{7}$ In terms of improvements to the operation of public procurement systems, notable examples include the increased reliance on the use of electronic, and especially Internetbased, systems (often called "e-procurement"). ${ }^{8}$ In addition, many governments are experimenting with new procurement vehicles, such as framework agreements and electronic reverse auctions, and new procurement schemes, including public-private partnerships. ${ }^{9}$ As each of these changes is contemplated, planned, implemented, and then assessed, government leaders and policy makers need a framework of analysis for decision making - a framework based on public procurement goals and understanding stakeholder interests.

In this article, we offer such a framework, building on the ideas in Steve Schooner's 2002 article, "Desiderata: Objectives for a System of Government Contract Law.," In "Desiderata," Schooner outlined nine objectives, or desiderata, of public procurement systems: competition, integrity, transparency, efficiency, customer satisfaction, best value, wealth distribution, risk avoidance, and uniformity. ${ }^{11}$ With these nine objectives as a starting point, we use stakeholder analysis to further develop the desiderata into a two-part framework to give policy makers and government leaders a tool for public procurement decision making. This framework of analysis is broadly useful for public procurement systems at different levels of government within a country as well as across national borders. Just as Schooner's "Desiderata" has contributed to

${ }^{6}$ See generally Servet Alyanak, An Overview of the Legal Rules Government Public Procurement in Turkey, P.P.L.R. 2007, 2, 125-43.

${ }^{7}$ See e.g., Republic of Lithuania, Law on Public Procurement (Dec. 22, 2005), available at http://www.vpt.lt/admin/uploaded/LawonPPnew.doc.

${ }^{8}$ See KnUt Leipold, World BANK, Electronic Government Procurement (e-GP) Opportunities \& Challenges, in MOdern LAW FOR GLOBAL COMMERCE CONGRESS TO CELEBRATE THE FORTIETH ANNUAL SESSION OF UNCITRAL VIENNA, (July 9-12 2007), available at http://www.uncitral.org/pdf/english/congress/Leipold.pdf.

${ }^{9}$ See, e.g., Commission of the European Communities, Green Paper on Public-Private Partnerships and Community Law on Public Contracts and Concessions, at 3 (Apr. 30, 2004), available at http://eur-lex.europa.eu/LexUriServ/site/en/com/2004/com2004_0327en01.pdf (last visited Jan. 2, 2008); Press Release European Union, Public Procurement: Consultation Shows Need for Clarification of EU Rules on Public-Private Partnerships (Dec. 5, 2005), available at http://europa.eu/rapid/pressReleasesAction.do?reference=IP/05/555\&format=HTML\&aged=0\&l anguage $=E N \&$ guiLanguage $=$ fr (last visited Jan. 3, 2008).

${ }^{10}$ Steven L. Schooner, Desiderata: Objectives for a System of Government Contract Law, P.P.L.R. 2002, 2, 103-10.

${ }^{11} \mathrm{Id}$. at 104-09. 
public procurement decision making, this analytical framework can help clarify, and perhaps inform, many of the debates raging around procurement reform - from the pros and cons of eprocurement in Chile ${ }^{12}$ to the controversy surrounding "competitive dialogue" in the European Union ${ }^{13}$ to the challenges of interagency contracting in the United States. ${ }^{14}$

\section{Part I: Competing Goals in Public Procurement}

As an introduction to our discussion about the competing goals in public procurement, we begin by comparing and contrasting the goals of public and private purchasing. The similarities and differences between public and private procurement are significant because, only by understanding these similarities and differences, can government officials, policy makers and other decision makers make informed decisions about their public procurement regimes. As discussed in this part, any procurement system, private or public, must reconcile, or choose between, competing goals. Although, in this Part, we are focused on identifying and discussing the competing goals in a public procurement system, it is worth mentioning at this point that there are also competing stakeholder interests that should play into decision making in terms of public procurement system design, development, and reform, as we discuss in depth in Part II. Thus, in Part I, we have organized our discussion of the competing goals along the following lines: the goals and constraints when we make an individual purchase; the goals and constraints when a private company makes purchases; and the goals and constraints in play when a public entity makes purchases and the interplay among these goals and constraints in the context of public procurement.

\section{Goals and Constraints in Individual Purchasing}

When we make purchases as private consumers - whether buying a laptop computer or hiring a contractor to do work on our home - as an individual, we have goals, even if we do not think of them in those terms. (And certainly don't use Latin labels for them). Unlike public procurement goals that may have formal implementation rules and structure, private purchase goals are generally adopted and implemented informally. Nevertheless, as individual purchasers, we do have goals, even competing goals, in the purchases we make. As individual purchasers, we want the best value for our hard-earned money (or in exchange for our limited resources). The best value varies by circumstance. When we purchase something where the choices are, or at least seem, indistinguishable except for price, the lowest price, of course, will represent best value. Our personal analysis about best value is generally informal and subjective; we likely

\footnotetext{
${ }^{12}$ Ruth Bradley, Chile Compra: Three Years On, Business CHILE, No. 237 (Sept. 2006),
} http://www.businesschile.cl/portada.php?w=old\&id=348\&s=0\&lan=en\&q=enviepormail.

${ }^{13}$ Council Directive 2004/18, arts. 28, 29, 43, 2004 O.J. (L 134), 0114 - 0240 (EU), available at http://eur-lex.europa.eu/LexUriServ/LexUriServ.do?uri=CELEX:32004L0018:EN:HTML.

${ }^{14}$ Federal Acquisitions and Contracting: Systemic Challenges Need Attention: Hearing Before the S. Comm. on Homeland Security and Governmental Affairs, 110th Cong. 9-10 (2007) (statement of David M. Walker, Comp. Gen.), available at http://www.gao.gov/new.items/d071098t.pdf. 
make the tradeoff between price and quality (and other factors) unconsciously, and we are not required to identify (for ourselves, the vendors, or anyone else) what selection evaluation criteria we used, or how these criteria were weighted in making the purchase decision.

Tradeoffs are the result of our competing goals for private purchases. For many of us, we want the purchasing process to be efficient. Especially for people who do not enjoy shopping, efficiency in shopping (when it is necessary) is very important. Arguably, efficiency is not a goal, but a constraint; thus, at most, it is a purchase process-related goal. When people say that they like to buy over the Internet, part of the appeal is often that it is efficient. But we may also be concerned about the risks of Internet purchases. For example, the skirt may not look as nice as it did on the screen or the vase will arrive damaged and returning it will be difficult or require time and effort the purchaser was trying to avoid by purchasing over the Internet. Deciding not to make purchases over the Internet because of these possible risks is a form of risk avoidance. Others seek risk avoidance by making large purchases only with credit cards with policies offering protection against risks of non-delivery or non-performance of the purchased goods or services. Like efficiency, risk avoidance is not really a goal of the procurement; it is more a constraint. It may, however, go beyond the purchasing process itself. For example, selecting a higher-priced widget may be driven by a desire to avoid the risk associated with the cheaper alternative.

When the person making the purchase (or at least paying for it) differs from the person who will use what is being purchased, we can separate recipient (end-user) satisfaction from best value as distinct goals. Best value always has a cost component; end-user satisfaction may not. Parents buying a car for their son or daughter may prefer a solid model because their best value analysis includes safety as well as cost; they may ultimately decide to purchase a more stylish car, however, because they suspect (or are told) that it will lead to greater recipient satisfaction.

\section{Goals and Constraints in Private Company Purchasing}

Private companies share many of the purchasing goals that individuals have, even though they may play out differently. A company's perception of whether a purchase constitutes good value for money, may, as with individual purchases, be measured in different ways in different contexts. Companies making purchases are concerned that their purchases achieve recipient satisfaction. Also, companies will seek cost savings and efficiency in the purchasing process and will want to avoid risk in that process. How, then, do companies differ from individuals in their procurement goals?

One common difference is the size of the typical purchase or procurement. Companies, like individuals, often make very small purchases. The Warren Buffetts among us may make personal purchases of an amount that would get attention at General Motors, but the overall average purchase in the corporate environment can safely be assumed to be larger than the average individual purchase. Because of the amount of money at issue, and because of corporate governance issues, companies typically have a more formal process for their purchases than we do as individuals. That more formal process may entail an institutionalization of the companies' procurement goals, as discussed below.

Even for small purchases, companies have to be concerned about the integrity of the procurement process, which usually means, in that context, the avoidance of self-dealing or theft of corporate resources by employees. For a company of any size, and certainly for all publicly traded companies, governance concerns underscore the importance of maintaining the integrity 
of the purchasing process. The larger the purchases, the more the company may insist on more uniformity in the procurement processes. That may be partly to avoid embezzlement: requiring well-kept books might be an instance where more formal, uniform processes also serve as a form of risk avoidance. There may be other motivations for uniformity as well. Uniform, formalized buying practices make it easier and less expensive to train purchasing department staff. More formal processes can also ensure that different options are considered before purchasing, which may help identify the best value.

\section{Goals and Constraints in Public Entity Purchasing}

All of these individual and private company purchasing goals and constraints are at play when a public entity is making purchases, whether the city of Annapolis buys traffic lights or the Air Force buys fighter jets. But these shared goals are not the only goals in public procurement. The fact that taxpayer funds are at work - and at risk - in public procurement causes some of these goals to shift in importance and even in nature. The fear of corruption increases the importance of integrity as a goal. Thus, associated with integrity are transparency and accountability, although, as discussed below, whether they are viewed as goals or means to achieve goals can be debated.

Quite separate, though, from private individual and corporate purchase goals is the goal of social and economic investment through the public procurement system. When the procurement system is used to put government funds in the hands of small businesses, womenowned businesses, or businesses owned by a particular ethnic group, the system serves a goal completely divorced from goals of efficiency, best value in the object being purchased, or recipient satisfaction.

Goals are also implemented differently in the public procurement context. First, in public procurement, goals may be set by law or regulation, thus reducing flexibility in specific purchases. Moreover, there are more players in the public procurement arena: government leaders, legislators, auditors, and other oversight bodies, as well as the media and nongovernmental organizations. But before we can understand the varied stakeholders and their interests, and how those interests interact with each other, we need to understand the varied goals of public procurement systems, building on the goals as first defined by Schooner in "Desiderata." We discuss these varied goals in clusters because of the relationships among and between these goals and constraints, and begin with the customer-focused cluster.

\section{Cluster 1: End User Satisfaction, Economy, Best Value, Efficiency, Risk Avoidance}

\section{End User Satisfaction}

Public procurement is about purchasing goods and services, and there are a variety of customers, or end users, within a public procurement system, ranging from soldiers needing weapons to retirees receiving social security benefits to civil servants requiring computers at their desks. The separation between purchaser and user that we saw when parents bought a car for their child is the norm in the world of government acquisition: the public procurement purchaser is rarely the end user, and may not understand the end user's needs (often stated as "requirements"). In the U.S., because of the potential for poor decision making due to the lack of appreciation of end user satisfaction, the 1990's procurement reforms increased the attention 
paid to recipient satisfaction. ${ }^{15}$ The introduction of contractor past performance as a mandatory evaluation criterion for all procurements over $\$ 100,000$ empowered the end user and reduced the likelihood that government buyers could effectively foist a poor performer on the user. This requirement reflected the idea that it was better to pay more to obtain a contractor with a good track record because of the likely increased odds of user satisfaction. ${ }^{16}$

\section{Economy (cost savings) and Best Value}

The desire for economy, or cost savings, is at work in every public procurement system. Some, indeed, would identify economy as a goal of the procurement system. We think that this focus on the marginal dollar is more accurately seen as a constraint, and one directly (and adversely) affecting end-user satisfaction. While we prefer regimes that procure goods and services to maximize end users' satisfaction, governments often cannot afford to do so due to budgetary constraints.

End-user satisfaction takes no account of cost (at least not when, as is typical in government, the purchaser is separate from the end-user), so that the competing concern of saving costs acts as a counterweight. A typical government user complaint about a procurement system is that they were forced to accept a lower-cost solution than they wanted. From the purchaser's point of view, what happened was that end-user satisfaction yielded to 'value for money,' or best value, as it is called in the U.S. Best value could thus be seen as the result of end-user satisfaction constrained by the need for economy.

What is historically extraordinary, however, is that, in the U.S. federal government's procurement reform drive of the 1990s, best value came to be viewed, not as a counterweight to end-user satisfaction, but as a means to it. Correctly or not, there was a widespread perception that economy (low cost) had too often become the norm, and 'best value' was proffered as a way to avoid being forced to choose the low-cost solution (often articulated as meeting the end user's 'minimum needs'). More specifically, during the 1990s, the predominant method of selecting contractors in the U.S. came to be cost/technical tradeoff, and the non-cost (or quality) side of that analysis typically reflected the recipient's interest in non-cost factors viewed as a means to ensure customer satisfaction. ${ }^{17}$

\section{${ }^{15}$ FAR § 10.001(a)(1) (requiring agencies to "[e]nsure that legitimate needs are identified and trade-offs evaluated to acquire items that meet those needs"); FAR \$11.203 ("Acquisition organizations shall communicate with customers to determine how well the requirements document reflects the customer's needs ....”).}

${ }^{16}$ FAR § 15.304(c)(3)(i); cf. FAR § 15.304(c)(3)(iii) ("past performance need not be evaluated if the contracting officer documents the reason past performance is not an appropriate evaluation factor for the acquisition").

${ }^{17}$ Acquisition Advisory Panel, Report to the Office of Federal Procurement Policy AND THE UNITED STATES CONGRESS, at 93 (Jan. 2007), available at http://www.acqnet.gov/comp/aap/24102_GSA.pdf ("Use of task and delivery order contracts by agencies for the acquisition of complex services on a best value basis has been increasing."); see also FAR § 15.303(b)(6). 
Today, federal procurements are often viewed as either 'low cost' or 'best value,' the two seen as alternative approaches, and tradeoffs are the norm. Although price is always a consideration, ${ }^{18}$ the tradeoffs, which may match cost against quality, past performance, and/or other non-cost factors, are typically subjective and give substantial discretion to the source selection officials to select the offer that represents the "best value" to the government. ${ }^{19}$ Discretion, at least this degree of discretion, is not the rule among all existing public procurement regimes. The bias in favor of price-related selection criteria remains in the World Bank procurement guidelines, presumably because best value tradeoffs - especially subjective tradeoffs - are seen as inherently non-transparent, capable of manipulation, and thus more conducive to corruption. There is also the fear that granting discretion to government officials facilitates abuse of that discretion. ${ }^{20}$ In the EU system, tradeoffs are permitted, but the weighting of cost and the non-price factors generally must be objective and announced in advance, so that the issue becomes which offer is the "economically most advantageous tender." 21 Thus, the EU, like the World Bank, remains unwilling to allow government officials to exercise subjective discretion in making best value tradeoffs.

\section{Efficiency}

Like economy, efficiency also acts as a constraint in public procurement, although, as with an individual making a purchase, efficiency may be seen as a goal in the purchasing process. Efficiency relates to the way a public procurement system works, not what it produces. In this sense, it can only be an interim or collateral goal or a constraint: an inefficient system may be undesirable, but an efficient system that produces bad results is hardly desirable. There is a temptation to think of something like "systemic efficiency" to refer to how well the system does its job and produces good outcomes. In our view, however, these are really not questions of efficiency, but rather of best value: does the system lead to the acquisition of high-quality goods or services at favorable prices?

1810 U.S.C. § 2305(a)(3)(A)(ii); 41 U.S.C. § 253a(c)(1)(B); Bean Stuyvesant, L.L.C. v. United States, 48 Fed. Cl. 303, 338 (2000) (quoting Lockheed Missiles \& Space Co. v. Bentsen, 4 F.3d 955, 958 (Fed. Cir. 1993).

19 Talbot \& Korvola, Comp. Gen., B-231569, 88-2 CPD 288; Intelcom Educational Services, Inc., Comp. Gen. B-220192.2, 86-1 CPD 83; Ecology \& Environment, Inc., Comp. Gen., B209516, 83-2 CPD 229.

20 The World BAnK, Guidelines: Procurement Under IBRD LOANS AND IDA CREDIT $\mathbb{9} 2.49$ (May 2004, revised Oct. 2006), available at http://siteresources.worldbank.org/INTPROCUREMENT/Resources/ProcGuid-10-06-ev1.doc (last visited Dec. 28, 2007) ("the bid with the lowest evaluated cost, but not necessarily the lowest submitted price, shall be selected for award”).

${ }^{21}$ Council Directive 2004/18, 2004 O.J. (L134) đI 46 (EU), available at http://eurlex.europa.eu/LexUriServ/site/en/oj/2004/1_134/1_13420040430en01140240.pdf. 
The key to efficiency is speed. When we say that a procurement system is very efficient, we often mean that it obtains goods and services quickly. In a public procurement system, however, efficiency often means more than quick delivery. Avoiding waste is also part of efficiency, and requesting from vendors only the information that is actually needed is part of efficiency in the public procurement process. Efficiency might also introduced, from the vendors' point of view, by providing a single point-of-entry for vendors interested in learning about upcoming procurements and ensuring that information provided to vendors is accurate and complete. $^{22}$

Efficiency often works hand in hand with uniformity. Where procurement processes are uniform across the government, uniform training for those processes can be prepared and provided across the government. Uniform training may lead to efficiencies because, for example, when unanticipated needs arise in response to a natural disaster in one part of the country, the government could more easily transfer contracting officers from other parts of the government into that region, where they could keep the procurement system moving efficiently. For vendors, too, uniformity creates efficiencies: if all agencies use the same proposal format, vendors can more efficiently respond to all agencies' requests for proposals using the same preparation method and procedure.

\section{Risk Avoidance}

Risk avoidance plays a significant role in public procurement systems, although the very term "avoidance” makes clear that it is a constraint, rather than a goal. At the systemic level, risk avoidance often plays out in internal controls (most commonly, documentation requirements and formal approval processes) designed to avoid corruption as well as fraud, waste, and abuse. ${ }^{23}$ The longstanding preference in the U.S. system for sealed bidding, with public opening of bids with price as the only award criterion, can be viewed as a risk avoidance mechanism. The EU prohibition on subjective cost and technical tradeoffs is also a risk avoidance mechanism because of the limited discretion. ${ }^{24}$ In fact, an entire system of rules-based acquisition can be viewed as a way of managing the risk inherent in the large amount of money spent in the public procurement process. Many of the features that distinguish the government marketplace from the commercial world, including standardized remedy-granting clauses that permit terminations for the convenience of the government, ${ }^{25}$ the use of government-specific specifications, and especially cost-related requirements, derive from the government's desire to limit the risk in dealing with

22 See e.g., Federal Business Opportunities, www.FedBizOpps.gov (last visited Oct. 22, 2007). FedBizOpps purports to be the government's single point of entry for Federal procurement opportunities over $\$ 25,000$.

${ }^{23}$ Sue Arrowsmith, The Past And Future Evolution Of EC Procurement Law: From Framework To Common Code?, 35 PuB. ConT. L.J. 337, 352 (2006).

${ }^{24}$ Miguel Rocha de Gouveia, The Price Factor in EC Public Tenders, 31 PuB. ConT. L.J. 679, 684-85 (2002).

${ }^{25}$ FAR § 49.101. 
contractors. ${ }^{26}$ While risk avoidance may not be a free-standing goal of public procurement systems, it is a theme that likely runs through every system.

\section{Cluster 2: Integrity, Uniformity, Transparency, Accountability, Competition}

This second goal cluster is centered on the procurement processes and how the processes appear to support public procurement decisions. Rather than the customer focus of the first goal cluster, in this cluster, the goals are separate from end user satisfaction, and often may operate to the detriment of end user satisfaction. Even so, integrity is a goal with a special place in the public procurement arena.

\section{Integrity}

Just as private corporations are concerned about embezzlement and good governance, integrity goes to the heart of every public procurement system. Because such a large percentage of a country's gross domestic product is at stake in public procurement - often more than 10 percent - protecting the integrity of the procurement system is critical. The opposite of integrity in this context is corruption, and fighting corruption is a challenge presented in every public procurement system, large and small, in economies both highly developed and still developing.

Integrity works with competition, transparency, and accountability. While sham competitions can occur in a system that lacks integrity, the more the actors know that they can and will be held accountable, the less likely they are to engage in corruption. Conversely, anything that reduces transparency tends to increase the risk of corruption and, therefore, undermine integrity. A lack of public information about the workings of the procurement system can lead to the appearance of corruption, as can any lack of uniformity or complexity, such as preferences or set-asides created as part of social and economic investment policies. Conversely, measures that require public notification of upcoming procurements and publication of solicitations, awards, and rulings on protests all promote integrity by increasing the transparency of the public procurement system.

While no one, in the U.S. or elsewhere, would argue that integrity is unimportant, many domestic critics argue that the complexities of the federal procurement system, many of which were put in place to protect the integrity of the system, undermine the efficiency of the system without providing adequate benefits. Before he became the Administrator of the Office of Federal Procurement Policy (OFPP) in 1993, Professor Steven Kelman criticized political unwillingness to give government officials sufficient discretion to exercise business judgment in making procurement decisions. ${ }^{27}$ This view, including the criticism of the complexities of the federal procurement process, is sometimes couched as one of trust, and specifically the lack of trust given by the public and government leaders and lawmakers to those people directly

\footnotetext{
${ }^{26}$ Truth in Negotiations Act of 1962, 10 U.S.C. § 2306(a) (2000); FAR § 15.402.

27 See generally Steven Kelman, Procurement and Public Management: The Fear of Discretion AND the Quality of Public Performance (American Enterprise Institute, 1990); but see generally Steven L. Schooner, Fear of Oversight: The Fundamental Failure of Businesslike Government, 50 AM. U. L. REV. 627 (2001).
} 
involved in making the procurement decisions. ${ }^{28}$ While at OFPP, Kelman promoted best value decisions and consideration of contractor's past performance, as well as expanded use of Indefinite Delivery - Indefinite Quantity (ID/IQ) contracts and task and delivery orders under them, all of which tipped the scales in favor of efficiency because of, at least in part, a perception that concerns about integrity had led to an overly complex, inefficient procurement process.

\section{Uniformity}

In public procurement, uniformity generally refers to standardization of rules and procedures, and it is usually measured between (and among) agencies and between (and among) procurements. In 1984, when CICA imposed a uniform procurement statute across (almost) the entire U.S. government and the Federal Acquisition Regulation imposed a uniform procurement regulation across (almost) the entire U.S. government, uniformity among agencies was at a high point. $^{29}$ Since then, uniformity has deteriorated, as various agencies, including the Federal Aviation Administration, were granted authority to create their own procurement regimes. ${ }^{30}$

The special competition rules are legion, and not limited to commercial items. Many rules vary depending on the bidder; there are different rules for small businesses and other targeted groups, and for vendors benefiting from (or disadvantaged by) domestic preferences such as the Buy American Act ${ }^{31}$ or the U.S.'s international trade agreements. ${ }^{32}$ The rules also vary by procurement vehicle, with different rules for ID/IQ and Federal Supply Schedule contracts and their associated task and delivery orders. These special rules may thwart uniformity, but no one would advocate following the same process for purchasing a box of paperclips and a jet fighter. Imposing uniform rules would result in unjustified inefficiency in the purchase of the paperclips or an inadequately considered acquisition of the jet fighter, or

${ }^{28}$ Air Force Lt. Gen. Charles Croom, director of the Defense Information Systems Agency, has been quoted as saying that the military has a need for "reducing the complexity of [their] processes and for more trust.” 21 FED. COMPUTER WK 12, Aug. 27, 2007.

${ }^{29}$ Even in 1984, some entities were outside the FAR system. See 39 U.S.C. § 410(a) (2000) (USPS not subject to most federal procurement laws and regulations, including the Competition in Contracting Act and the Federal Acquisition Regulation). Non-Americans are often surprised to learn that the U.S. has no uniformity between federal procurements and those conducted at the state and local levels. In contrast, the EU procurement directives, for example, apply to the procurements of the city of Paris as much as to those of the French central government.

${ }^{30}$ But see 41 U.S.C. § 405(a) (2000) ("The Administrator of the Office of Federal Procurement Policy is authorized and directed . . . to promulgate a single, simplified, uniform Federal procurement regulation and to establish procedures for insuring compliance with such provisions by all Federal agencies.”).

${ }^{31} 41$ U.S.C. §§ 10(a)-10(b) (2000); FAR § 25.1101.

${ }^{32}$ FAR § 25.402. 
both. Uniformity, then, may serve as little more than a constraint in the sense that lack of uniformity breeds inefficiency.

\section{Transparency}

While, in theory, transparency could mean visibility within an agency, in the public procurement context we usually use the term in the context of outsiders (anyone outside the inner workings of the government's procurement process) seeing into the procurement organization's operations. In particular, transparency permits outside stakeholders to see what and how the government buys. Transparency is praised so widely that one might assume that it is an end in itself, but, generally, it serves to promote another goal of the procurement system - integrity. The widely accepted assumption is that, as transparency increases, corruption decreases. For this reason, the World Bank and others on the international stage promote transparency as a key area for improvement in developing countries' public procurement systems. ${ }^{33}$ Similarly, the U.S. has seen efforts to make procurement data, especially data about the award of contracts, readily available to the public. ${ }^{34}$ True transparency begins before the procurement starts-letting the world know what the government intends to buy. Transparency continues through every stage of the procurement - making the solicitation widely available, writing in the solicitation a clear explanation of what the government wants and how it will choose the winning contractor, publicly announcing the winner, and making public the result of any protest or other challenge to the selection decision. Governments generally rely upon publication-providing notice to the public — as the way to achieve transparency. Today, the Internet has reduced the cost and effort of promoting transparency, and some middle-income countries, such as Chile and Mexico, have developed web-based systems that excel in sharing procurement-related information. ${ }^{35}$

33 THE WORLD BANK, supra note 20, at 1.2(d).

34 The Accountability in Contracting Act, H.R. 1362, 110th Cong. (2007) would change federal acquisition law to require agencies to limit the use of "non-competitive contracts" and cost plus contracts. Purporting to increase transparency, the legislation would make justification and approval documents for sole source or limited competition publicly available. Furthermore, the legislation contemplates that fixed price contracts provide the government a better value at a lower risk when costs are well understood.

${ }^{35}$ See Chile Compra, https://www.chilecompra.cl/Portal/InicioPortal.aspx (last visited Apr. 25, 2008); CompraNET, http://compranet.gob.mx/ (last visited Apr. 25, 2008); see also WTO News Press Release, WTO Members look at growing use of Internet in government procurement, PRESS/104 (29 June 1998), at http://www.wto.org/english/news_e/pres98_e/pr104_e.htm; The World Bank, Chile’s Government Procurement E-System, http://web.worldbank.org/WBSITE/EXTERNAL/TOPICS/EXTINFORMATIONANDCOMMU NICATIONANDTECHNOLOGIES/EXTEGOVERNMENT/0,,contentMDK:20486003 isCUR L:Y menuPK:1767268 pagePK:210058 piPK:210062 theSitePK:702586,00.html (last visited Apr. 25, 2008); Carlos Jaso, Compranet: Electronic System for Government Procurement in Mexico (Jan. 2, 2001), 


\section{Accountability}

Accountability is not a goal of public procurement systems, in the sense that those systems do not exist merely to be called to account. Accountability, however, often is a means to reduce corruption in a public procurement system, or at least decrease the appearance of corruption. Accountability is about holding government officials responsible for procurement actions. $^{36}$ That entails requiring officials to document their actions throughout the procurement process, being called to defend their actions when challenged, and, if required, being punished for violating the rules. As with transparency and integrity, accountability can be viewed as a constraint and it is often at odds with efficiency.

\section{Competition}

Like accountability, competition is not a goal in itself. But for public procurement systems, competition is seen as a way to obtain the best value, which is a goal public procurement systems share with individual purchasers and private companies. ${ }^{37}$ Individuals and private companies may not talk or think in terms of competition, though; they are more likely to talk and think about the process for choosing a vendor as "shopping around" or conducting market research. Nonetheless, all sensible purchasers, public and private, understand they frequently benefit from comparing the prices and quality offered by multiple vendors before making a purchase decision. In the public procurement sphere, we usually combine these two aspects of competition: government buyers actively request proposals or invite bids and tell the vendors that they are in a competition with others. (Indeed, even when only one vendor submits an offer, the government buyer generally does not tell the vendor that, hoping that, even in the absence of actual competition, the fear that there may be competition will help the government get the best deal.) We assume, without much, if any, empirical data to support it, that competition leads to lower prices and higher quality.

Competition is also a means to fight corruption: letting an outside vendor compete for work that has regularly gone to a long-term contractor may disrupt "cozy” relationships between the incumbent and acquisition staff or users. Competition improves both transparency and accountability, because an unsuccessful competitor may have an interest in demanding public information about why it did not obtain a contract; bid protests, which can inject transparency and accountability into a public procurement system, are generally filed by disappointed bidders. For all these reasons, even though competition is often treated as a goal in itself (witness the statutory title, Competition in Contracting Act of 1984), it is more accurately seen as a means to achieve other public procurement goals.

http://wbln0018.worldbank.org/OCS/egovforum.nsf/c3c9b2819079a45d852569bc007722a0/332 966893c199a1d852569cb006d247b/\$FILE/compranet0201presentation.pdf (last visited Apr. 25, 2008).

${ }^{36}$ Accountability has been a big issue in recent Congressional efforts to improve the federal procurement system, including the recently passed H.R. 1362, the "Accountability in Contracting Act.” H.R. 1362, 110th Cong. (2007).

${ }^{37}$ FAR $\S 6.101$. 
In addition to acting as a means to other public procurement goals, competition is also a restraint on efficiency. Competition is often at odds with, or at least perceived to be at odds with, efficiency, because generally, the competition process slows things down. ${ }^{38}$ In terms of tension among goals, efficiency is often at odds with competition, transparency, and best value. There are, of course, situations in which an agency is needlessly and unjustifiably inefficient, and, in those cases, efficiency can be improved without any cost to competing goals. In many instances, however, improving efficiency, especially in the near term, carries a price, in terms of losing some competition, transparency, and risk avoidance.

\section{Non-clustered Extraneous Goals}

In addition to the customer satisfaction goal cluster and the integrity goal cluster, there are goals within a public procurement system that are extraneous to the procurement system.

\section{Investment through Targeted Procurement}

Targeted procurement ${ }^{39}$ is used by governments to give business opportunities to disadvantaged individuals, groups, or communities, and is intended to create and sustain jobs and alleviate poverty. ${ }^{40}$ Through this investment, the procurement system - and especially the money that flows through it - becomes a means to goals that are themselves separate and distinct from the procurement system. The means adopted for meeting these social and economic investment goals may include reserving certain procurements for the favored group (set-asides), giving these groups an advantage in the procurements (a cost advantage, for example), or some other means. Some supporters of these policies claim that favoring a particular group will lead to other benefits, such as more competition, to the entire procurement system. More typically, though, these benefits are external to the procurement system: society wants to help these groups, and social and economic investment in the procurement system, with the enormous amount of money that runs through it, is a convenient way to help. No doubt social and economic investment can sometimes help the targeted groups, and support for this investment may be quite strong. As with tax benefits, however, this investment can appear to be a no-cost form of assistance to the favored group; thus it is tempting, particularly for politicians seeking to curry favor with the groups, to support such policies.

There are costs to these targeted procurement efforts, however, some more obvious than others. Best value and recipient satisfaction may be sacrificed to achieve a statutorily-imposed

\footnotetext{
${ }^{38}$ See, e.g., ACQUISITION ADVISORY PANEL, supra note 17, at 9-10 (discussing concerns about balancing competition and efficiency).

${ }^{39}$ Schooner called this “wealth distribution” in his "Desiderata.” See generally Schooner, supra note 10 .

${ }^{40}$ Ron Watermeyer, The Use of Targeted Procurement as an Instrument of Poverty Alleviation and Job Creation in Infrastructure Projects, P.P.L.R. 2000, 5, 226-50, at 227; see also Ron Watermeyer, Facilitating Sustainable Development Through Public and Donor Procurement Regimes: Tools and Techniques, P.P.L.R. 2004 30-55, at 38-46 (containing a detailed discussion of the objectives of public procurement systems, including socio-economic goals).
} 
percentage goal for dollars awarded to small businesses. Uniformity is reduced when special rules and procedures are introduced to accommodate the benefits given to small disadvantaged businesses. Competition is reduced when procurements are set aside for small businesses. Transparency is blocked when firms self-certify as to their size status and the government has difficulty knowing whether they are truly small. Integrity is undermined when an Alaskan Native corporation is found to have few Alaskan Natives among its owners and employees. It should be pointed out, too, that there is little empirical evidence that targeted procurement policies actually help the targeted groups.

Now that we have described the competing goals of public procurement systems, we turn to a discussion about the holders of these competing goals, the public procurement stakeholders. Unlike in the private purchasing sphere, where the stakeholders are generally limited to buyers and sellers, in the public procurement sphere, the stakeholders include buyers and sellers. But that is only the starting point. Public procurement stakeholders have a broad scope of interests as well as a varied level of participation in actual procurement transactions. In Part II, we further develop our analytical framework by layering in the stakeholders and their interests in public procurement.

\section{Part II: Stakeholders in the Public Procurement Arena}

In making choices that will lead to a viable, rational, and credible public procurement system, governments and policy makers should identify who and what their public procurement system serves, and consider these stakeholder interests in their decision making. ${ }^{41}$ Stakeholder analysis in public procurement is underdeveloped. Many authors use the word "stakeholder" in articles about different aspects of public procurement, but there is a dearth of sources that identify and define these stakeholders and their interests. ${ }^{42}$ Even when authors have noted the

${ }^{41}$ In discussing the concept of public value within the public choice theory, and how public procurement systems can achieve public value, Andrew Kidd explained that "[p]ublic value is based on the perceptions and expectations of the stakeholder rather than a quantified set of measures. This presents a dilemma in that the expectations of various stakeholder groups may not be consistent .... [T] he expectations and perceptions of other stakeholders influence and inform the expectations of the key funding stakeholders.” Andrew Kidd, Procurement's Value: What Are We Really Measuring?, in Advancing Public Procurement: Practices, InNOVATION AND KNOWLEDGE-SHARING 414 (Gustavo Piga and Khi V. Thai, eds. 2007).

42 See, e.g., Jerrell D. Coggburn, Exploring Differences in the American States' Procurement Practices, 3 J. Pub. Procurement 3, 14 (2003) (discussing the "diversity of interests represented in procurement”); Christopher R. Yukins \& Steven L. Schooner, Incrementalism: Eroding the Impediments to a Global Public Procurement Market, 38 GEO. J. INT’L L. 529, 565 (2007) ("We have long perceived that this fundamental issue —identifying and understanding the interests and priorities of the various stakeholders in public procurement-is a critical yet underexplored piece of the public procurement policy puzzle.”); Christopher R. Yukins, Integrating Integrity and Procurement: The United Nations Convention Against Corruption and the UNICITRAL Model Procurement Law, 36 PUB. ConT. L.J. 307, 308 (2007) (“A fully transparent 
value in recognizing and understanding stakeholder interests in the public procurement sphere, they have not focused on defining and describing these interests. ${ }^{43}$ In his "Desiderata," Schooner referred to some of the public procurement stakeholders, without actually calling them stakeholders, in his discussion on the competing public procurement goals. ${ }^{44}$ By understanding stakeholder interests, government leaders and policy makers can weigh the competing stakeholder interests and effectively account for these interests, if they so choose, at any stage of public procurement - design, development, or reform. ${ }^{45}$ Our analysis here relies on the federal procurement system of the United States for much of the context, even though that system is not necessarily a model public procurement system for other governments. But, as the largest public procurement system in the world, the U.S. experience provides a great deal of failures and successes that can be analyzed to produce much of this stakeholder analysis. ${ }^{46}$

procurement system, for example, is far less likely to have problems with integrity, for many more stakeholders can exercise oversight in a transparent procurement system.”).

${ }^{43}$ See Cliff McCue \& Eric Prier, Using Agency Theory to Model Cooperative Public Purchasing, in Advancing Public Procurement: Practices, InNovation AND KNOWLEDGe-Sharing 4546 (Gustavo Piga and Khi V. Thai eds., 2007). In this chapter, Cue and Prior provide a framework for thinking about and applying agency theory to cooperative public purchasing. One reason why "agency theory is a fruitful method for modeling cooperative public purchasing is that it helps to identify the various incentives of the stakeholders. By clarifying the opportunities and constraints they face, hope is engendered that efficiency, effectiveness, and accountability will be increased.” Id. at 50. They identify several stakeholders: citizens, businesses, governments, and potential vendors and suppliers. See id. at 51.

${ }^{44}$ In his discussion about the competing goals of public procurement, Schooner, without using the term "stakeholder" or "stakeholder interests" discusses private industry, government agencies, and the public. Schooner, supra note 10, at 104-08.

45 This concept of stakeholder analysis is not new. In 2007, OECD discussed the value of stakeholder involvement in "scrutinizing integrity in public procurement" and described stakeholders - "private sector, end users, civil society, the media or public at large" - as mechanisms for ensuring integrity in public procurement systems. OECD, supra note 3, at 117. The World Bank has also used stakeholder analysis, in developing models for reform. See The World Bank, Operationalizing political analysis: the Expected Utility Stakeholder Model and governance reforms, PREM NoTES, Public Sector, No. 95, (Nov. 2004 ).

${ }^{46}$ See ACQUisition AdVISORY PANEL, supra note 17, at 1 ("The Federal government is the single largest buyer in the world. Each year, federal agencies spend nearly $\$ 400$ billion for a range of goods and services to meet their mission needs.”). 


\section{Inside Public Procurement Stakeholders}

\section{The Government}

The category of government as stakeholder is complicated and multifaceted, in part because of the multiple layers of government within a national or sub-national government. ${ }^{47}$ As a starting point for defining the government as stakeholder, government leaders and officials in both the executive and legislative branches are likely to be interested in maintaining their positions within the government. ${ }^{48}$ This selfish interest translates to the public procurement sphere because these leaders seek to avoid scandal and the specter of corruption to maintain their positions in government. Government leaders are interested in a viable and supported public procurement system, and a system built on appropriate and effective legislation, because they are generally blamed for problems and scandals in public procurement. These government leaders are also interested in having a system that is flexible and capable of meeting the government's needs - needs ranging from repainting a federal building to purchasing enough body armor for the armed forces on the battlefield. ${ }^{49}$

Legislators are also stakeholders. Some legislators' interests in procurement reform are driven by the scandal or problem of the moment. As elected officials, legislators may have an interest in public procurement as a means to an end in terms of running for election on a platform of procurement reform, promising their constituents an end to fraud, waste and abuse by an existing administration. ${ }^{50}$ A legislator's constituency often has its own interests, which may differ, at least in part, from the public's interests, and a legislator may adopt those constituency-

${ }^{47}$ Our discussion of the government as stakeholder is simplified both in terms of restricting context to the United States and in terms of broadly identifying the stakeholders and their interests.

${ }^{48}$ For elected officials, reelection may be a constant concern. Even for those government leaders not elected, it is fair to assume they are generally interested in maintaining their positions, or at least, in having the choice to leave a government position instead of being fired or otherwise removed.

${ }^{49}$ In this article, we do not specifically discuss the Executive branch procurement as far as the President and other administration officials are concerned. We do, however, discuss the executive agencies and their roles in carrying out procurements, including as directed by Executive leaders.

${ }^{50}$ See e.g., Robert Brodsky, Contracting Offices Face Increased Oversight, GOVERNMENT EXECUTIVE (Aug. 28, 2007), http://www.govexec.com/dailyfed/0807/082807rb1.htm. ("Within weeks of assuming control of Congress, Democrats initiated a renewed level of oversight of procurement, shining a light on noncompetitive deals, mismanaged and wasteful contracts and ethical missteps at the General Services Administration. Procurement reform now has become a hot topic on Capitol Hill, and companies are preparing - albeit begrudgingly - for some of the most significant contracting legislation in recent memory.”). 
unique interests. Legislators responsible for appropriating government funds are a distinct subcategory of stakeholders within government because of their unique role. These appropriators often have short-term political goals that may be antithetical to long-term procurement decisions and policy, and appropriators' decisions contribute to the notable lack of coherent policy in the existing federal procurement regime in the United States.

In addition to the executors, legislators and appropriators, other government employees work within the acquisition workforce. These workers include program managers, and the military and civilian personnel responsible for managing government programs and requirements. Program managers are interested in meeting their specific program's product or service needs within the appropriated/budgeted money. Unlike agency leaders who likely have broader interests in all the agency's programs, program managers are less likely to be concerned about the broad policy implications of a particular procurement decision, and more likely to be concerned about getting their product or service delivered on time. Often looking for ways to speed up the procurement process and ultimately the delivery of goods or services to end users, program managers also have an interest in having a flexible procurement system, a system that provides choices for contract types, or vehicles, in different circumstances. ${ }^{51}$

Finally, there are the end users, or government customers. Here, we mean the government employees or armed forces that need and rely upon the government-procured goods and services, as distinct from our discussion about The Public as end user, infra. Generally, the government end users are not as interested in the broad goals of a public procurement system because of the nature of their positions; they are not concerned with the methods or procedures that lead to the ultimate delivery, but are interested in having their needs met in a timely manner.

Government end users give high priority to efficiency in the procurement process, because, to them, increasing efficiency means faster receipt of the goods or services they need. ${ }^{52}$ As a goal of a public procurement system, the value placed on efficiency in the form of speed varies dramatically among stakeholders, and here, as with several other goals, there is tension among government stakeholders. For the members of the acquisition workforce, however, speed of the overall procurement process may be perceived as a constraint as much as a goal. They know that they will be criticized if the procurement process takes too long to deliver goods or services to the end users, but the acquisition workforce must juggle the end users' demands for "goods now!" against the need to maximize competition, transparency, and accountability (in the form, typically, of documenting all steps), which takes time. ${ }^{53}$

${ }^{51}$ See Coggburn, supra note 42.

52 See e.g., Robert O’Harrow, Jr., Federal No-Bid Contracts on the Rise, WASH. Post, Aug. 22, 2007, A1, at A8 (quoting the director of the U.S. government's counter-narcotics' office: "My goal was to get this done as quickly and efficiently as possible.”).

${ }^{53}$ See id. (quoting the chief investigator at Taxpayers for Common Sense, a non-partisan watchdog group, "Contracting officials are throwing out decades of work to develop fair and sensible rules to promote competition .... Government officials are skirting the rules in favors.”). 


\section{Outside Public Procurement Stakeholders}

Turning now to the outside stakeholders, we focus on parties who do not directly play a role in the public procurement process, but are invested in the process for a variety of reasons.

\section{The Public}

In the public procurement context, The Public is the largest of all the outside stakeholders. We employ the "The Public" to mean those members of society who, because of their relationship to the government as taxpayers, have an interest in how the government spends money. Here, we refer to The Public stakeholder as distinct from other identified stakeholder groups, ${ }^{54}$ and The Public is a multifaceted stakeholder with varied interests. Even though it may be difficult to identify all of The Public's possible interests and the relative importance of these interests, just as with the inside stakeholders, we attempt here to provide a starting point. There are several interests that are likely to be consistent among taxpayers, and governments and policy makers should consider these interests in their public procurement system design, development, and reform efforts.

At the most basic level, The Public favors wise government spending, and The Public's other interests all derive from this basic interest. ${ }^{55}$ The Public in any society is a constant and dependable stakeholder because public procurement systems generally rely on money from The Public through taxes for government expenditures. The Public may not necessarily be interested in having the government spend the least amount of money as possible on a particular product or service, but The Public is likely interested in how the government spends money in terms of getting the best value for the government dollar, or at least in terms of not wasting money, or avoiding the appearance of wasting money.

Closely related to wise government spending, The Public may expect the government to operate its procurement system with integrity, or, without corruption. The Public may want a procurement system rooted in fairness, not in corrupt practices designed to benefit individuals and corporations at government (and taxpayer) expense. ${ }^{56}$ These two interests, wise spending and the avoidance of corruption, are closely related because The Public may (incorrectly, we fear, simply) associate high cost procurement with corruption. Transparency in public procurement increases The Public's access to public procurement information, but even so, The Public is insufficiently informed about government spending decisions, and this incomplete information may cause The Public to question even wise government spending decisions. For

${ }^{54}$ For example, Government-elected officials (inside stakeholders) are also taxpaying members of society (outside stakeholders).

55 See Kelman, supra note 27, at 96 ("Taxpayers in general have a right, however, to expect dollars spent on procurement to maximize the value the government receives.”).

${ }^{56}$ Corruption avoidance has long been recognized as part of The Public's interest. See e.g., id. at 96 ("Public corruption can devastate the ethical tone of society as a whole and decrease the inclination of citizens to behave ethically in their everyday lives.”). Kelman also recognized that The Public's perceptions may not be accurate - "the public tends to exaggerate the problem more than practitioners within government tend to underestimate it.” Id. 
example, The Public may perceive a raw dollar amount spent on a particular procurement as extravagant, and therefore the result of corrupt practices, even when the government, in fact, received excellent value for its money. ${ }^{57}$

The Public may also be interested in a public procurement system that is flexible and responsive to national emergencies and can provide the needed goods and services. In terms of this interest, The Public, or at least a portion of The Public, becomes a customer or end user of government-procured goods and services. This interest may be demonstrated by The Public's reactions to government attempts to deal with national security issues and natural disasters with widespread, even national, impact. Thus, The Public as a stakeholder has multiple layers of interests depending on the particular role, as taxpayer or as end user (or customer).

\section{The Oversight Community}

This category of stakeholders is made up of accountability enforcers such as distinct groups of legislators, GAO, and the judicial branch, as well as non-governmental third-party interest groups and observers. Even though GAO and the courts are governmental bodies, in terms of our inside-outside public procurement stakeholder dichotomy, they are outsiders to the public procurement process. In addition, non-governmental interest groups and the media play major roles in contributing to the oversight of public procurement because of their function in providing information to The Public. All of the groups within this category of outside stakeholders, although motivated by different interests, provide information, evaluation, and criticism of public procurement. Transparency is thus the interest par excellence of these outside stakeholders, since it is what lets them know what's transpiring inside.

The oversight community rarely praises, commonly criticizes, and can often digress into a "gotcha" mode with respect to efficiency and competing goals. Thus, if it takes an agency many months to conduct a full and open competition, the press, academics, and oversight officials (whether from the legislature or audit agencies) may criticize the agency for inefficient procurements. If, instead, the procuring agency moved efficiently to award the contract, those same oversight officials, academics, and journalists would not hesitate to criticize the agency if it

57 The Public's reaction to news about government contract awards may be the result of inadequate or incomplete information. For example, a newspaper may report a recent billiondollar contract award, which may seem outrageous on its face, but does not report that the awardee was the lowest price offeror, or that the costs to build the particular good are justified. The Media regularly reports contract awards. See, e.g., Essex wins \$8.5M Air Force contract, ST. LOUIS Bus. J., Nov. 9, 2007, available at http://www.bizjournals.com/stlouis/stories/2007/11/05/daily86.html (reporting contract award “worth up to $\$ 8.5$ million to provide emergency passenger oxygen systems (EPOS) to the U.S. Air Force”).

The Department of Defense also regularly reports recent contract awards, including information about contracting activity, type of contract, whether competed and locations of performance. See, e.g., Press Release, Department of Defense, Contracts (Nov. 9, 2007), available at http://www.defenselink.mil/contracts/contract.aspx?contractid=3645. 
turned out there was less than full and open competition, or the agency failed to discover a potential conflict of interest, or otherwise conducted an exhaustive analysis of other possible problems prior to award.

\section{Government Oversight}

Within the government, in addition to the inside stakeholder legislators and appropriators, there are also outside stakeholders acting in their capacity as accountability enforcers, including legislative committees, inspectors general and other auditors, individual elected officials, government attorneys, and GAO. ${ }^{58}$ Although part of the government, these stakeholders, in their particular oversight and accountability roles, are outside stakeholders because they are responsible for identifying problems in public procurement; investigating fraud, corruption, and waste; providing recommendations and solutions; and ensuring that the acquisition workforce and other government employees responsible for carrying out procurement procedures do so within the law and policy restrictions of the procurement system.

\section{Non-Government Oversight}

In addition to the government bodies required to carry out their oversight and accountability enforcement roles, there are also non-government oversight bodies. These thirdparty oversight community members merit consideration because they influence The Public, as well as elected officials and other members of the government. Third-party observers of public procurement may have a variety of interests, but generally, they are interested in a procurement system that functions with integrity and without corruption. In seeking this goal, interest groups, such as POGO and TI, function as investigative and reporting bodies that work to make information publicly available, in an effort to encourage reform within an existing public procurement regime.

Although not an interest group like POGO and TI, the media (all sources and formats) is another stakeholder in the non-governmental oversight community category. Governments and policy makers should consider the media's role and interests in a public procurement system, because news involving public procurement often highlight corruption and other negative aspects of an existing procurement system. Although the media does not cause corruption and misconduct, the media is responsible for the choices about what and how to report -- choices that dramatically affect The Public's perception.

Finally, academics, similar to the other third-party observer stakeholders, have an interest in providing information to government leaders, policy makers, and The Public to encourage certain decisions in public procurement design, development, and reform. For example, in this article, we are providing information to policy makers and government leaders for use in making their public procurement decisions. Academics also serve as critics of existing public procurement systems, and may write articles or books that influence how the government does

\footnotetext{
${ }^{58}$ GAO, 1 Principles of FEDERAL APPROPRIATIONS LAW 1-21 (3d ed. 2004), available at http://www.gao.gov/special.pubs/d04261sp.pdf.
} 
business, or at least call attention to the potential errors or inconsistencies in public procurement systems. $^{59}$

\section{Private Stakeholders}

Private companies make up the final major category of outside stakeholders. Generally, private stakeholders include businesses with existing relationships as government contractors providing goods and services to the government, and those businesses trying to break into the potentially lucrative government contract business. Even though they differ in size and type of good produced or service provided, most private stakeholders share a common interest: profit. Within this category of profit-motivated private stakeholders, there are several distinct subcategories including the largest defense contractors, new businesses trying to win government contract awards, small businesses seeking special preferences and opportunities to win government contract awards, not-for-profits, and foreign companies trying to gain access to global public procurement markets.

All of these private corporate stakeholder interests compete with each other, and with the other stakeholders including government buyers. Buyers usually want vendors to know that their prices and quality are being compared against those of others, on the assumption that that knowledge serves as an incentive to the vendors to offer their best prices and highest quality. This pressure on vendors is an example of Adam Smith's "invisible hand,"60 the force of the market causing sellers to strive to defeat their competitors. Consumers have witnessed the power of saying: "Your competitor told me they'd sell this to me for X dollars - can you beat that price?” In this vendor-focused competition, the vendor may respond to this information to encourage the buyer to make the purchase, and the buyers may be more or less passive.

Finally, not-for-profit organizations, including academic institutions and research centers such as, in the U.S., University Affiliated Research Centers (UARC) and Federally Funded Research and Development Corporations (FFRDC), are private stakeholders. FFRDCs -government agency-sponsored centers for research and development designed to meet specific government needs - the government to access private resources for carrying out research and development, which otherwise may not be available for government use. ${ }^{61}$ These FFRDCs are stakeholders primarily because they exist within the structure of the Federal Acquisition Regulation as government-sponsored entities, and they are interested in maintaining relationships with their sponsoring agencies and the government in general because they are funded, at least in part, by this government business. Although not limited to defense-related research and development, much of the research and development performed by these not-for-profits is within the Department of Defense. Primarily, money motivates these organizations; thus, they prefer a procurement system that allows the government to have relationships with them.

${ }^{59}$ See, e.g., Kelman, supra note 27; Steven L. Schooner, Fiscal Waste? Priceless: Citing Disaster Relief, The Limit On Thousands Of Federal Charge Cards Has Been Raised To $\$ 250,000$ Per Purchase, L.A. Times, Sept. 14, 2005, at B13.

\footnotetext{
${ }^{60}$ AdAm SMith, AN INQUiRY INTO THE NATURE AND CAUSES OF THE WEALTH OF NATION 477 (Edwin Cannan ed., Chicago Univ. Press 1976) (1850).

${ }^{61}$ FAR $\S 35.017$.
} 


\section{International Trade Organizations}

This category of outside stakeholders may not initially appear to matter to an individual country's or government's public procurement system. That vision is short-sighted, however, because public procurement is increasingly a global issue. ${ }^{62}$ No country can afford to alienate itself from the global marketplace - either because it will lose opportunities to compete in other markets, or because it will not reap the benefits open markets would bring - increased competition and perhaps increased quality to its own public procurement system. Stakeholders in this category are organizations interested in transparency and uniformity in public procurement standards and procedures as a way to increase access and involvement in global markets, and develop the global economy in public procurement.

One of the most significant and influential stakeholders is the World Trade Organization. With the base assumption that governments are interested in achieving "'value for money,"” or best value, the WTO encourages an open, transparent, and non-discriminatory public procurement system. ${ }^{63}$ The WTO also recognizes that even when governments share these goals of open markets, transparency and non-discrimination, competing interests within a country's procurement regime may inhibit total openness, rendering transparency and non-discrimination unlikely. This is because many countries, including the U.S., use public procurement as a way to reach social and economic policy goals. ${ }^{64}$

Even with these limitations, the WTO seeks to resolve conflicts and barriers within existing public procurement regimes to create harmonization among procurement regimes, and increase international access and international trade in public procurement. In working toward this goal, the WTO's Agreement of Government Procurement (GPA) defines agreed upon rights and obligations for its members. ${ }^{65}$ For example, with a focus on avoiding domestic favoritism, the GPA requires fair treatment of domestic and foreign services and suppliers. ${ }^{66}$ The GPA also has standards for procurement procedures aimed at increasing equitable treatment of foreign services and suppliers by ensuring both foreign and domestic potential contractors are on an equal playing field with regard to procedure. ${ }^{67}$ Under the GPA framework, countries are not

62 See generally Christopher R. Yukins \& Steven L. Schooner, Incrementalism: Eroding the Impediments to a Global Public Procurement Market, 38 GEO. J. INT’L L. 529, (2007).

${ }^{63}$ WTO, Government Procurement, http://www.wto.org/english/tratop_e/gproc_e/gproc_e.htm (last visited Oct. 4, 2007).

${ }^{64} I d$.

${ }^{65}$ WTO, Government Procurement: General Overview of WTO Work on Government Procurement, http://www.wto.org/english/tratop_e/gproc_e/overview_e.htm (last visited Oct. 4, 2007).

${ }^{66}$ WTO, Overview of the Agreement on Government Procurement, http://www.wto.org/english/tratop_e/gproc_e/gpa_overview_e.htm (last visited Oct. 4, 2007).

${ }^{67}$ WTO, The Plurilateral Agreement on Government Procurement, Jan. 1, 1996, available at http://www.wto.org/english/tratop_e/gproc_e/gp_gpa_e.htm (last visited Jan. 8, 2008). 
discouraged from entering the global procurement marketplace because there are standards set up to decrease barriers to that entry. Also, through GATS, the WTO is interested in making the procurement of services similarly international and open to the global marketplace, as a way to distribute wealth internationally and help public procurement regimes reach their likely goals of best value and value for money. ${ }^{68}$

Even though transparency seems calculated to improve procurement systems, it is not always without controversy. In 1996, the WTO set up the multilateral Working Group on Transparency in Government Procurement to conduct a study on transparency in government procurement practices. Taking into account national policies, the group was tasked to develop elements suitable for inclusion in an appropriate agreement. ${ }^{69}$ After several years of work, the WTO found too much resistance to come to an agreement, and, since 2004, the Working Group on Transparency has been inactive. ${ }^{70}$ The main reason for this failure can be traced to developing nations' perceptions that transparency would serve primarily as a wedge to open their procurement markets up to developed countries' vendors. ${ }^{71}$ The perception that transparency was a proxy or code for "market access" doomed the initiative because of the fear of negative economic consequences - losing business to other countries' companies. ${ }^{72}$ For some, then, even though transparency may reduce access barriers to the government marketplace, that may not always be a good thing.

Similar to the WTO, the OECD encourages opening public procurement to international competition instead of succumbing to protectionism. The OECD, made up of 30 countries, provides research and analysis in a number of areas including sustainable economic growth, world trade, living standards and employment around the world. ${ }^{73}$ The OECD also encourages the closely-related goals of corruption-avoidance and integrity in public procurement systems, and to that end, publishes studies and policy recommendations to encourage opening public procurement to global markets. For example, the OECD’s 2007 report entitled “Integrity in

${ }^{68}$ WTO, GATS Negotiations on Services Procurement, http://www.wto.org/english/tratop_e/gproc_e/gpserv_e.htm (last visited Oct. 4, 2007).

${ }^{69}$ WTO, Working Group on Transparency in Government Procurement, http://www.wto.org/English/tratop_e/gproc_e/gptran_e.htm (last visited Dec. 8, 2007).

${ }^{70} I d$.

${ }^{71}$ See The Center for International Development at Harvard University, Global Trade Negotiations Homepage, Government Procurement Summary, at http:/www.cid.harvard.edu/cidtrade/issues/govpro.html (last visited Feb. 11, 2008).

${ }^{72}$ See id.

${ }^{73}$ OECD, About the OECD, http://www.oecd.org/pages/0,3417,en_36734052_36734103_1_1_1_1_1,00.html (last visited Oct. 4, 2007). 
Public Procurement: Good Practice from A to Z”74 leaves no question about OECD’s interest in creating and maintaining integrity in public procurement systems. The OECD noted that "[p]ublic procurement has been identified as the government activity most vulnerable to corruption."75 To avoid the opportunities for corruption, the OECD prefers public procurement systems rooted in transparency and accountability, but unlike some of the other stakeholders with single-minded interests, OECD notes that these interests "must be balanced with other good governance imperatives, such as ensuring an efficient management of public resources ... or providing guarantees for fair competition."76 Thus, although OECD’s main interest appears to be integrity in public procurement, there is some room for compromise and recognition of other stakeholder interests.

Finally, the United Nations Commission on International Trade Law (UNCITRAL) is also interested in the harmonization of public procurement systems as a way to increase international trade. ${ }^{77}$ With 60 member states, UNCITRAL encourages harmonization through model laws, including a model law on procurement.

\section{Conclusion}

We offer no single answer here to the question of what goals government leaders and policy makers should seek to satisfy in designing, developing, and reforming their public procurement systems. Similarly, and possibly as unsatisfying, we do not identify the single stakeholder interests should be allowed to influence government leaders and policy makers in their public procurement system decisions. Instead, as we set out to do, we present a framework of analysis about public procurement stakeholder interests and the goals of public procurement systems. Individual governments must make decisions about which stakeholder interests to recognize and which goals to seek in the design, development, and reform of public procurement systems. These decisions, however, are more likely to lead to good, politically acceptable, public procurement systems when government leaders and policy makers thoughtfully and carefully weigh the competing stakeholder interests and overall public procurement system goals.

${ }^{74}$ OECD, supra note 3.

${ }^{75}$ Id. at 9.

${ }^{76}$ Id. at 10.

${ }^{77}$ See UNCITRAL, THE UNCITRAL GUIDE 1 (2007), available at http://www.uncitral.org/pdf/english/texts/general/V0650941.pdf; UNCITRAL, Origin, Mandate and Composition of UNCITRAL, http://www.uncitral.org/uncitral/en/about/origin.html (last visited Oct. 4, 2007) ("The General Assembly gave the Commission the general mandate to further the progressive harmonization and unification of the law of international trade.”). 